\title{
BRANCH JUNCTION CHARACTERISTICS AFFECT HYDRAULIC SEGMENTATION IN RED MAPLE
}

\author{
By Nathan J. Eisner'1, Edward F. Gilman², Jason C. Grabosky³, and Richard C. \\ Beeson, Jr. ${ }^{4}$
}

\begin{abstract}
The effect of branch morphological characteristics on hydraulic segmentation in red maple branch junctions was determined using hydraulic conductivity measurements. Relative branch size impacted hydraulic conductivity at the branch junction. Conductivity ratios were directly proportional to the ratio of branch diameter to stem diameter. Junctions with perpendicular branches showed lower hydraulic conductivities than more upright branches. The presence of visible branch collars was a good indicator of low branch junction conductivity. Branches having pith that was continuous with trunk pith were associated with codominant stems that had high branch junction conductivity. Branch junction hydraulic conductivity was positively correlated with the amount of discolored wood development after branch removal. This finding may indicate that similar anatomical properties are responsible for both branch junction decay resistance and hydraulic segmentation.

Key Words. Aspect ratio; branch angle; codominant stems; compartmentalization; discolored wood; hydraulic architecture; hydraulic conductivity; pruning; Acer rubrum.
\end{abstract}

Previous research of hydraulic architecture of forest trees examined tree morphology and wood anatomy to describe the mechanics of water ascent (Zimmermann 1983). This research has helped to explain the growth habits, water distribution, biomechanics, and drought tolerance of trees (Ewers and Zimmermann 1984). Tree morphology and wood anatomy dictate the hydraulic architecture of trees by their effect on the hydraulic conductivity or, conversely, on the resistance of xylem to water flow (Comstock and Sperry 2000).

Size and density of conduit elements (tracheids or vessels) in wood largely determine the hydraulic conductivity of a stem. Stem water flow is often modeled as capillary movement through a collection of tubes (Niklas 1992). The Hagen-Poiseuille law describes hydraulic conductivity as being proportional to the diameter of the conduit raised to the fourth power. Because wider conduit elements contribute dispropor- tionately $\left(\mathrm{d}^{4}\right)$ to total conductivity, any increase in mean conduit diameter dramatically increases the waterconducting capacity of a stem (Tyree and Ewers 1991).

Hydraulic conductivity is also affected by conduit element length. The highest resistance in the hydraulic pathway occurs at the ends of vessels or tracheids, as water flows from one conduit element into the next via perforations or pits in the conduit end walls (Zimmermann 1978). Therefore, increased conduit element length decreases resistance over a fixed distance by reducing the total number of end wall crossings. Such an increase in mean vessel length increases the hydraulic conductivity of a stem (Comstock and Sperry 2000).

Studies of hydraulic architecture led to the concept of hydraulic segmentation within trees (Zimmermann 1978, 1983). Hydraulic segmentation refers to any structural feature that prioritizes water flow through the main stem to the terminal apex. Segmentation helps maintain an intact water column in the tree's main stem, confining drought-induced cavitations to expendable, lateral branches (Tyree and Ewers 1991).

Hydraulic segmentation has been attributed to a zone of increased hydraulic resistance at the branch junction. This resistance is due to several anatomical properties of wood within branch junctions (Ewers and Zimmermann 1984; Aloni et al. 1997). The conduit elements of branch junctions tend to be shorter and narrower than in surrounding tissue. The presence of nonfunctioning, circular xylem vessels, which constrict water movement, has also been associated with branch junctions (Lev-Yadun and Aloni 1990). Water movement may be further constricted in these junctions by an abrupt change in vessel orientation, as branch tissues turn downward to merge with the trunk (Shigo 1985; Tyree and Ewers 1991). The purpose of this branch junction anatomy may be twofold. By reducing flow into lateral branches, a greater proportion of available water remains in the main stem to ensure a dependable supply of water to the upper 
canopy (Zimmermann 1978). Constrictions in the branch junction may also serve to prevent spread of embolisms from branch to trunk. Were this spread to occur, a relatively minor embolism originating in a lateral branch could lead to blockage of the trunk water column (Zimmermann 1983).

Most studies of hydraulic segmentation have used small, lateral branches with low aspect ratios. Aspect ratio is used to express relative branch size and is equal to the branch diameter divided by trunk diameter measured at the branch junction (Eisner et al. 2002). Although hydraulic segmentation has been observed in branch junctions where aspect ratio was small, little is known about how it may vary over the range of possible aspect ratios. It is also not known if hydraulic segmentation is affected by other branch junction morphological characteristics such as the angle of branch attachment and presence of branch collars.

Branch junction morphology affected the amount of discolored wood that developed after branch removal (Eisner et al. 2002). Anatomical features including conduit element size and density affected decay resistance of wood in several hardwood species (Eckstein et al. 1979). However, the relationship between hydraulic resistance and decay resistance of branch junctions after branches are removed is unknown.

The objectives of this study were to (1) quantify the relationship between aspect ratio and hydraulic segmentation in red maple branch junctions; (2) test the impact of branch morphological characteristics such as branch angle, branch collars, and pith connection on the hydraulic conductivity of branch junctions; and (3) test the relationship between branch junction hydraulic resistance and decay resistance after branch removal.

\section{MATERIALS AND METHODS}

\section{Part One: Hydraulic Conductivity Measurement}

The 25 red maple (Acer rubrum L.) trees in this study were grown from seedlings and had calipers ranging from 14 to $18 \mathrm{~cm}$ (5 to $7 \mathrm{in}$.) with an average height of $4.5 \mathrm{~m}$ (15 ft). The trees were growing in Gainesville, Florida, U.S. (USDA Plant Hardiness Zone 8b) on a well-drained Millhopper Sand (loamy, siliceous, hyperthermic Grossarenic Paleudults) soil. Sample branch junctions were selected based on aspect ratio. Average branch and trunk diameters were measured at $15 \mathrm{~mm}$ (0.6 in.) above the branch bark ridge and used to calculate aspect ratio. One branch representing each of
Table 1. Branch aspect ratio categories were used to select branch junction for measuring hydraulic conductivity. Aspect ratio $=$ branch diameter $\div$ trunk diameter.

\begin{tabular}{cc}
\hline Aspect ratio category & Branch aspect ratios \\
\hline A & $0.21-0.40$ \\
B & $0.41-0.60$ \\
C & $0.61-0.80$ \\
D & $0.81-1.00$ \\
\hline
\end{tabular}

four aspect ratio categories (Table 1) was selected on each tree for a total of 100 branch junction samples (4 categories $\times 25$ trees). Only branches 10 to $20 \mathrm{~mm}$ (0.4 to 0.8 in.) in diameter were selected for study.

In January 2001, branch junction samples were harvested from trees using a pruning saw. Trees were dormant at the time of harvest. Branch junctions were cut, leaving approximately $20 \mathrm{~cm}$ (8 in.) of intact trunk wood both above and below the branch junction and a $20-\mathrm{cm}$ branch stub to prevent movement of embolisms into the branch junction, which would complicate the measurement of hydraulic conductance (Sperry et al. 1988). Samples were then immediately submerged in ice water for transport to the lab for immediate analysis.

All samples were immersed in tap water for a minimum of 15 minutes to fully hydrate the tissue (Sperry et al. 1988). Samples were then recut while submerged to prevent embolism formation, using a small pruning saw. Final cuts were made transversely through the trunk at $5 \mathrm{~cm}$ (2 in.) above the branch bark ridge and $5 \mathrm{~cm}$ below the bottom of the branch. The branch was cut in a similar way, leaving an 8-cm (3-in.) branch stub. All cut ends were then smoothed while still submerged using a razor blade. Gaskets of rubber tubing were slipped over the basal end of each sample and secured with a hose clamp to provide a leakproof connection to the conductivity apparatus (Figure 1).

Each branch junction was then connected, via a gasket adapter, to an apparatus for measuring hydraulic conductivity as described by Sperry et al. (1988). This apparatus delivered distilled, filtered $(0.20 \mu \mathrm{m})$, degassed water to the basal end of the sample under a gravitational pressure head of $18.0 \mathrm{kPa}\left(2.6 \mathrm{lbs} / \mathrm{in}^{2}\right)$. The fluid was forced acropetally through the branch junction for five minutes to allow flow to equilibrate throughout the sample. After equilibration was completed, fluid was perfused through samples for another five minutes and the mass flow (water flow in grams) ex- 


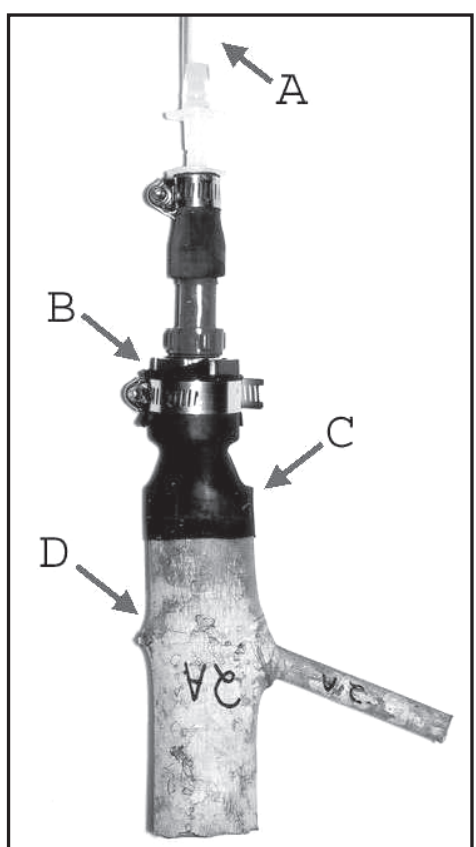

Figure 1. A red maple branch junction fitted into gasket adapter showing delivery tube (A), adapter body (B), inner-tube gasket $(C)$, and a branch junction (D).

through the trunk), the length of each path was measured (Sperry et al. 1988). Each sample was split with a wedge along the medial longitudinal plane, exposing the branch and trunk pith (Figure 2). Trunk path length was measured as the linear distance of the trunk pith through the entire sample $(A B+B D$, Figure 2). Branch path length was measured as the sum of the linear distances of trunk pith below the branch junction and the entire branch pith $(\mathrm{AB}+\mathrm{BC}$, Figure 2). A protractor was used to measure the angle between branch pith and trunk pith below the branch junction to quantify the angle of branch attachment $(<\mathrm{ABC}$, Figure 2). Presence of branch collars and pith connections were also noted. Branch collars were defined as obvious swellings of trunk tissue around the base of a branch. Pith connections existed if branch pith and trunk pith were continuous.

To compare hydraulic capacity of the branch to the trunk, mass flow (m) was converted to specific conductivity $\left(\mathrm{K}_{\mathrm{sp}}\right)$ by the following equation where

$\mathrm{s}=$ time (seconds)

$\mathrm{A}=$ cross-sectional area of the distal end of the path (branch or trunk)

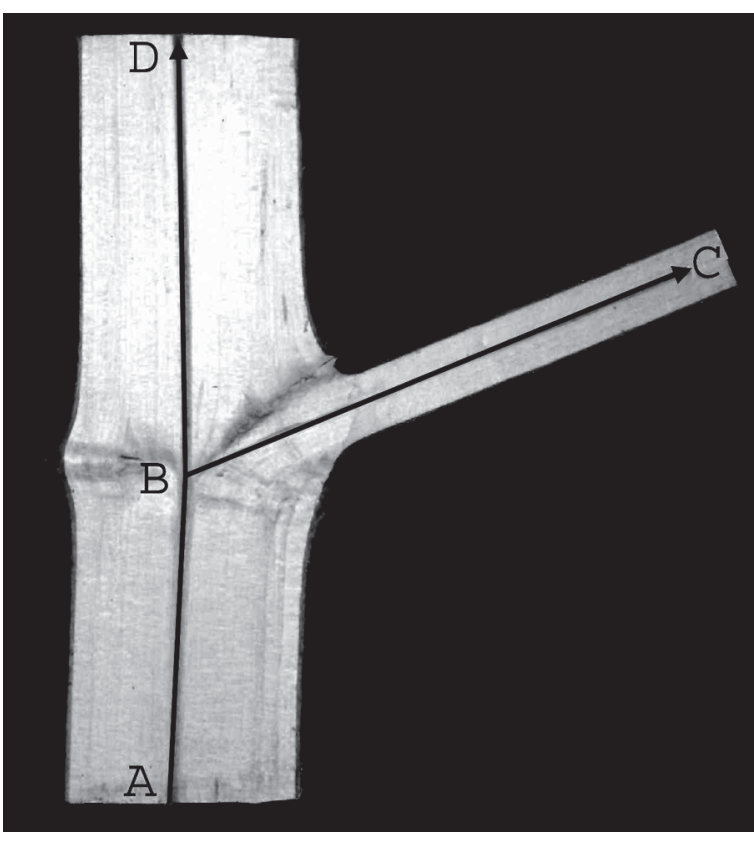

Figure 2. The medial longitudinal surface of a dissected red maple branch junction illustrating the measurement of branch junction morphology. Trunk path length was measured as the sum of segments $A B$ and $\mathrm{BD}$. Branch path length was measured as the sum of segments $A B$ and BC. Angle of branch attachment ( $\angle A B C)$ was measured below the branch junction.

$$
\begin{aligned}
& \Delta \mathrm{P}=\text { pressure head } \\
& l=\text { path length } \\
& \qquad \mathrm{K}_{\mathrm{sp}}=\frac{\mathrm{ms}^{-1} \mathrm{~A}^{-1}}{\Delta \mathrm{P} / l}
\end{aligned}
$$

After specific conductivity was calculated for each sample, a conductivity ratio $\left(R_{k}\right)$ was calculated by dividing branch specific conductivity by trunk specific conductivity. The conductivity ratio served as a measure of hydraulic constriction at the branch junction. Increasing hydraulic constriction was represented by a decreasing conductivity ratio.

The relationship between hydraulic constriction within a branch junction and branch morphological characteristics was evaluated using SAS (SAS Institute Inc. version 8.0). The general linear models (GLM) procedure was used to test the impact of continuous variables (aspect ratio and branch angle) on conductivity ratio. Tukey's studentized range (HSD) test was used to test the impact of class variables (presence of 
branch collars and pith connections) on conductivity ratio.

\section{Part Two: Hydraulic Conductivity vs. Decay Resistance}

To test the impact of hydraulic properties of the branch junction on its decay resistance after branch removal, hydraulic measurements from Part One were compared with discoloration data from morphologically similar branches from a previous study (Eisner et al. 2002). In that study, red maple branches of varying aspect ratios were removed to test the impact of branch aspect ratio on trunk discoloration. Trunk discoloration and aspect ratio were related according to the following equation:

$$
\begin{aligned}
& \text { Discolored area }= 0.27(\text { aspect ratio })^{2}-0.004 \\
& r^{2}=0.77
\end{aligned}
$$

Codominant stems, which have aspect ratios approaching 1 , were more prone to trunk discoloration after removal than were small lateral branches.

Conductivity ratio data from the one hundred red maple branch junctions described in Part One were paired with discoloration data. Aspect ratio was used as the criteria for pairing because of its high correlation with both discolored area $\left(\mathrm{r}^{2}=\right.$ 0.77, Eisner et al. 2002) and conductivity ratio. To balance the data sets (120 discoloration vs. $100 \mathrm{R}_{\mathrm{k}}$ values), 20 discoloration values whose aspect ratios most poorly corresponded with aspect ratios of the hydraulic conductivity data were discarded. Paired discoloration and conductivity ratio values were analyzed using the general linear models (GLM) procedure to test the relationship between conductivity ratio and the amount of discoloration that developed after branch removal.

\section{RESULTS AND DISCUSSION Part One}

The conductivity ratio of red maple branch junctions increased significantly $(P<0.001)$ as aspect ratio increased toward one (Figure 3). In other words, as branches approached conductivity). a codominant condition, hydraulic constriction in the branch junction decreased. Zimmermann (1978) made similar measurements in several diffuse-porous tree species, where hydraulic conductivity of subordinate branches (aspect ratio $<0.5$ ) was approximately one-half of trunk conductivity. These results also agree with Tyree and Ewers (1991) who found no significant hydraulic constriction occurring in the junctions of codominant stems of Acer saccharum. Here, hydraulic constriction at the branch junction decreased linearly over the range of aspect ratios, from subordinate branches to codominant stems.

The angle of branch attachment had a significant positive impact on the conductivity ratio. This ratio increased due to greater conductivity of the branch junction when branches had a vertical orientation relative to the trunk regardless of the branch aspect ratio (Figure 4). As branch orientation approached vertical (branch angle $=180^{\circ}$ ), water flow through the branch junction increased. Angle of branch attachment likely affects water flow through the junction by deflection of conduit elements in the branch, as they turn downward to merge with the trunk (Shigo 1985). Therefore, conduit elements in a branch that is oriented perpendicular to the trunk must deflect more sharply than those of more upright branches, in order to join with trunk tissue.

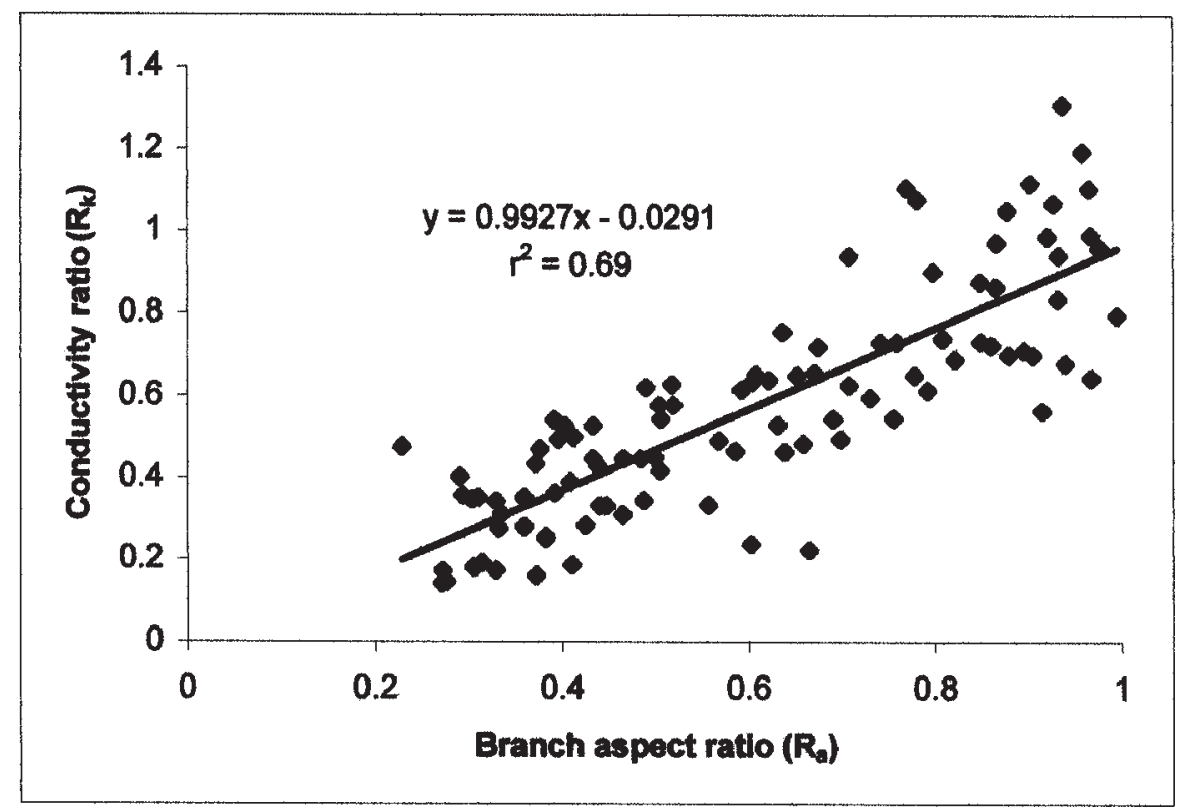

Figure 3. Impact of branch aspect ratio on the amount of hydraulic resistance in red maple branch junction as measured by conductivity ratio (conductivity ratio $=$ branch specific conductivity $\div$ trunk specific 


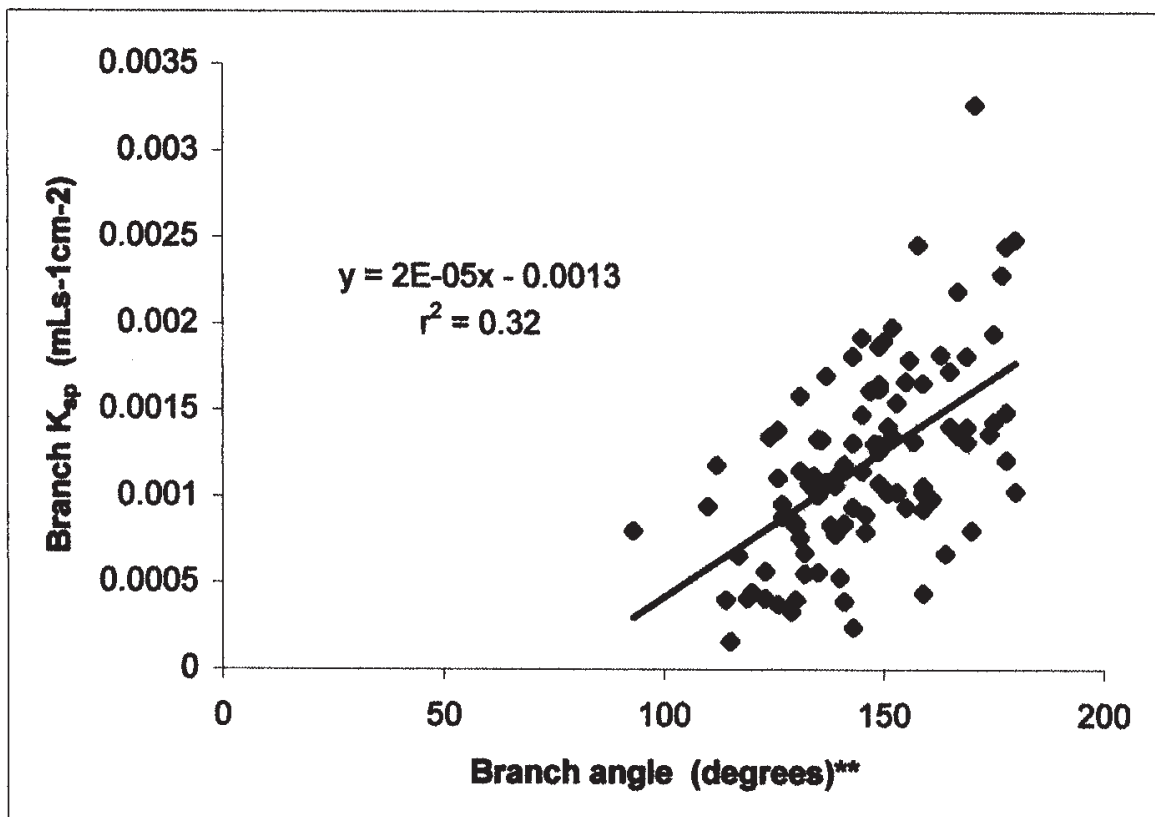

Figure 4. Impact of angle of branch attachment impact on the specific conductivity of water through red maple branch junctions. Branch angle was measured as the angle formed between branch and trunk pith on the lower side of the branch as visible in medial longitudinal sections of the branch junction.

Forty-one branch junctions possessing visible branch collars were sampled. Hydraulic conductivity ratios were significantly less for branches with visible branch collars $\left(\mathrm{R}_{\mathrm{k}}=0.36\right)$ than for those without collars $\left(\mathrm{R}_{\mathrm{k}}=0.73\right)$. Aspect ratio was also significantly lower for branches with collars $\left(\mathrm{R}_{2}=0.42\right)$ than for branches lacking collars $\left(\mathrm{R}_{\mathrm{a}}=0.74\right)$. Branch collars were most common on subordinate (small aspect ratio) branch junctions having low conductivity ratios. This finding suggests that branch collars may be useful indicators of the presence of anatomical properties responsible for hydraulic constriction within red maple branch junctions in addition to their utility in predicting wound compartmentalization potential (Eisner et al. 2002).

Fifteen branch junctions having branch pith that was continuous with trunk pith below the junction were sampled. The mean conductivity ratio for branches with pith connections $\left(\mathrm{R}_{\mathrm{k}}=0.80\right)$ was significantly higher than for those without pith connections $\left(\mathrm{R}_{\mathrm{k}}=0.54\right)$. The mean aspect ratio for branches with pith connections (aspect ratio $=0.73$ ) was also significantly higher than for branches without (aspect ratio $=0.59)$. Branches with pith connections were seen more often in branches in codominant branches with high conductivity ratios. Continuous pith from branch to trunk may occur when the branch being measured was, at one time, a terminal leader that lost its dominance due to injury or shading, whereupon a lateral branch took over as the terminal leader. Because these "branch leaders" do not possess constrictive anatomy at their base, they are normally associated with high conductivity ratios in codominant stems (Spicer and Gartner 1998).

\section{Part Two}

There was a significant $(P<0.001)$ positive correlation between branch: trunk conductivity ratio and the amount of trunk discoloration that developed after branch removal in morphologically similar branch junctions of red maple (Figure 5). This finding indicated that red maple branch junctions having high conductivity ratios would likely develop more severe trunk discoloration than branches with low conductivity ratios if the branch were to be removed. Increased trunk discoloration and hydraulic conductivity with increasing aspect ratio may occur due to the change of wood anatomy at the branch junction. Both trunk discoloration and conductivity have been independently correlated with wood anatomy (Eckstein et al. 1979; Comstock and Sperry 2000). It is possible that branch junction wood anatomy is responsible for hydraulic segmentation and decay resistance of subordinate branches of red maple.

These results support past observations of hydraulic segmentation at the junctions of subordinate branches (i.e., low aspect ratios). Subordinate branches are common structural features of many forest trees, due to competition for light associated with a closed canopy. In contrast, codominant branching (i.e., aspect ratio $=$ 1 ) is prevalent in many urban trees. It is not known if this latter type of tree structure, with its poor segmentation, represents a hydraulic liability to urban trees. Little information is available on the impact (if any) of tree branching structure on tree survival. Shigo (1986) observed that some forest trees developed canopies with codominant branching patterns once their height had surpassed neighboring trees. But these same trees 
were unable to resume vigorous height growth later when competition from neighboring trees resumed. It is possible that loss of hydraulic segmentation that accompanies codominant branching may inhibit further height growth.

High specific conductivity of codominant stem junctions may have other implications for tree health. Codominant stem junctions, having more and larger conduit elements than subordinate branch junctions, may conduct water more efficiently but at the cost of mechanical support and pathogen defense capability due to their containing lower densities of xylem fibers and parenchyma cells (Tyree and Ewers 1991). Codominant stem junctions were more susceptible to mechanical breakage (Lilly and Sydnor 1995) and trunk discolora-

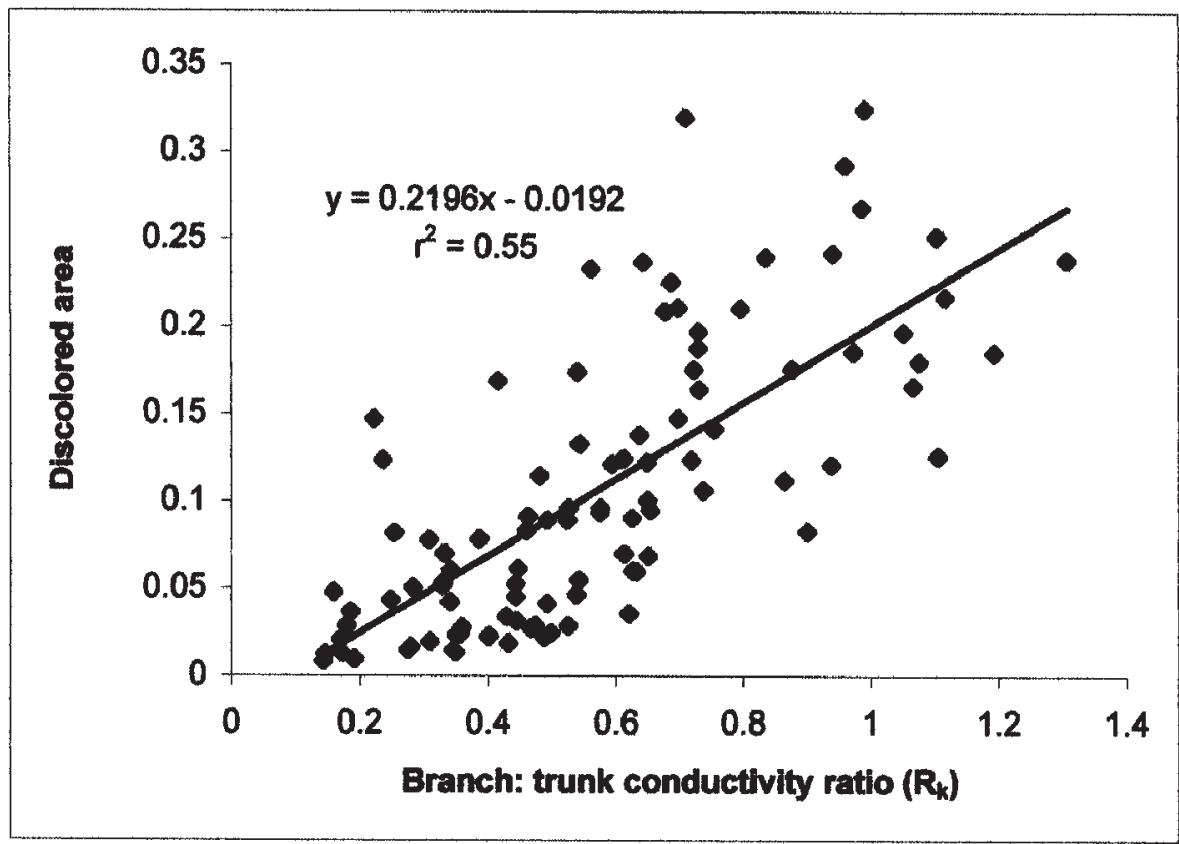

Figure 5. Normalized area of discolored wood $\left[\log _{10}\right.$ discolored area $\left(\mathrm{cm}^{2}\right) \div$ trunk cross-section area $\left.\left(\mathrm{cm}^{2}\right)\right]$ that developed on the medial longitudinal surface of red maple branch junctions four months after branch removal as correlated with conductivity ratio of morphologically similar branch junctions having similar aspect ratios. tion (Eisner et al. 2002) after prun-

ing than subordinate branches. In addition, hydraulic conductivity was inversely related to mechanical strength in stems of several shrub species (Wagner et al. 1998).

It is apparent that a branch junction's morphology also impacts its hydraulic properties. Although arborists do not manage wood anatomy directly, they do affect tree form and branching structure through pruning. Therefore, it is important to understand the patterns of water allocation in trees. A thorough understanding of the wood anatomy responsible for hydraulic segmentation is also important because of the impact this anatomy may have on other facets of tree health. Further research is needed to learn more about these interconnections and the role they play in tree health, longevity, and safety.

\section{CONCLUSIONS}

In summary, the ratio of branch specific conductivity to trunk specific conductivity increased with increasing branch aspect ratio. Branches oriented upright in relation to the trunk showed less resistance to water movement through the branch junction than branches oriented perpendicular to the trunk. Junctions with visible branch collars had lower conductivity ratios than junctions without collars. Branches having pith continuous with trunk pith had higher conductivity ratios than branches that lacked these pith connections. There was a significant correlation between hydraulic conductivity and the amount of trunk discoloration that developed after branch removal in morphologically similar branch junctions of red maple.

\section{LITERATURE CITED}

Aloni, R., J.D. Alexander, and M.T. Tyree. 1997. Natural and experimentally altered hydraulic architecture of branch junctions in Acer saccharum Marsh. and Quercus velutina Lam. trees. Trees 11:255-264.

Comstock, J.P., and J.S. Sperry. 2000. Theoretical considerations for optimal conduit length for water transport in vascular plants. New Phytol. 148:195-218.

Eckstein, D., W.C. Liese, and A.L. Shigo. 1979. Relationship of wood structure to compartmentalization of discolored wood in hybrid poplar. Can. J. For. Res. 9:205-210.

Eisner, N.J., E.F. Gilman, and J.C. Grabosky. 2002. Branch morphology impacts compartmentalization of pruning wounds. J. Arboric. 28(2):96-102.

Ewers, F.W., and M.H. Zimmermann. 1984. The hydraulic architecture of balsam fir (Abies balsamea). Physiol. Plant. 60:453-458.

Lev-Yadun, S., and R. Aloni. 1990. Vascular differentiation in branch junctions of trees: Circular patterns and functional significance. Trees 4:49-54. 
Lilly, S., and T.D. Sydnor. 1995. Comparison of branch failure during static loading of silver and norway maples. J. Arboric. 21:302-305.

Niklas, K.J. 1992. Plant Biomechanics: An-Engineering Approach to Plant Form and Function. University of Chicago Press, Chicago, IL. 670 pp.

Shigo, A.L. 1985. How tree branches are attached to trunks. Can. J. Bot. 63:1391-1401.

—. 1986. A New Tree Biology. Shigo and Trees, Associates. Durham, NH 595 pp.

Sperry, J.S., J.R. Donnelly, and M.T.Tyree. 1988. A method for measuring hydraulic conductivity and embolism in xylem. Plant Cell Environ. 11:35-40.

Spicer, R., and B.L. Gartner. 1998. How does a gymnosperm branch (Pseudotsuga menziesii) assume the hydraulic status of a main stem when it takes over as leader? Plant Cell Environ. 21:1063-1070.

Tyree, M.T., and F.W. Ewers. 1991. The hydraulic architecture of trees and other woody plants. New Phytol. 119:345-360.

Wagner, K.R., F.W. Ewers, and S.D. Davis. 1998. Tradeoffs between hydraulic efficiency and mechanical strength in the stems of four co-occurring species of chaparral shrubs. Oecologia 117:53-62.

Zimmermann, M.H. 1978. Hydraulic architecture of some diffuse porous trees. Can. J. Bot. 56:2286-2295.

- 1983. Xylem structure and ascent of sap. In Timmel, T.E. (Ed.). Springer Series in Wood Science. Springer, New York, NY.

Acknowledgments. Thanks to the International Society of Arboriculture Research Trust for providing partial funding of this project. Florida Agricultural Experiment Station journal series no. R-08811

${ }^{1 *}$ Former Graduate Student
${ }^{2}$ Professor
${ }^{3}$ Assistant Professor
${ }^{4}$ Associate Professor
Environmental Horticulture Department
1549 Fifield Hall
University of Florida
Gainesville, FL 32611
*Corresponding author.

Résumé. L'impact des caractéristiques morphologiques des branches sur la segmentation hydraulique au niveau des jonctions de branches de l'érable rouge a été déterminé au moyen de mesures de la conductivité hydraulique. La dimension relative de la branche avait un impact sur la conductivité hydraulique à la jonction de la branche. Les ratios de conductivité étaient directement proportionnels au ration du diamètre de la branche sur celui de la branche-mère. Les jonctions avec des branches perpendiculaires avaient de plus faibles conductivités hydrauliques que celles des branches plus ascendantes. La présence de collets visibles autour des branches était un bon indicateur d'une conductivité plus faible au niveau de la jonction. Les branches qui avaient une moelle continue avec celle du tronc ont été associées à des branches codominantes qui avaient une forte conductivité hydraulique au niveau de la jonction de la branche. La conductivité hydraulique de la jonction de la branche était corrélée positivement avec la quantité de bois décoloré qui s'est développée après la coupe de cette même branche. Ceci pourrait indiquer que des propriétés anatomiques similaires sont responsables à la fois pour la résistance contre la carie au niveau de la jonction de la branche ainsi que pour la segmentation hydraulique.

Zusammenfassung. Durch Messungen der hydr. Leitfähigkeit wurde der Einfluss von morphologischen Asteigenschaften bei der hydr. Segmentierung bestimmt. Die relative Astgröße beeinflusste direkt die hydr. Leitfähigkeit an der Astgabelung. Die Leitfähigkeitsverhältnisse waren direkt proportional zu dem Verhältnis des Astdurchmessers zum Stammdurchmesser. Gabelungen mit waagerechten Ästen zeigten weniger hydr. Leitf. Als mehr aufgerichtete Äste. Die Anwesenheit von sichtbaren Astkragen war ein guter Indikator für die niedrige Leitfähigkeit von Astgabelungen. Äste mit Kernholz, welches zum Stammkern eine Verbindung hat, waren ähnlich wie kodominante Stämme mit einer hohen Leitfähigkeit in der Gabelung versehen. Die Leitfähigkeit von Astgabeln ist positiv korreliert mit der Menge an verfärbtem Holz nach einer Astentfernung. Das könnte ein Indikator dafür sein, dass gleiche morphologische Verhältnisse verantwortlich sind für die Fäulnisresistenz von Astgabeln und für die hydr. Segmentierung.

Resumen. Se determinó el impacto de las características morfológicas sobre la segmentación hidráulica en la unión de las ramas en arce rojo usando mediciones de conductividad hidráulica. El tamaño relativo de la rama impactó la conductividad hidráulica en la unión de la rama. Las relaciones de conductividad fueron directamente proporcionales a la razón del diámetro de la rama al diámetro del tronco. Las uniones con ramas perpendiculares mostraron más baja conductividad hidráulica que las ramas más erectas. La presencia de collares de la rama visibles fue un buen indicador de baja conductividad de unión de la rama. Las ramas con descomposición, continuas con el tronco, estaban asociadas con ramas codominantes que tuvieron alta conductividad de unión. La conductividad hidráulica de unión de la rama estuvo positivamente correlacionada con la cantidad de madera decolorada, desarrollada después de la remoción de la rama. Esto puede indicar que propiedades anatómicas similares son responsables tanto de la resistencia al decaimiento de la unión de la rama como de la segmentación hidráulica. 